\title{
Entegre Et Tesislerinde Atık Suyun Yeniden Kullanımı
}

\author{
Recycling of Wastewater From Meat Processing Industry
}

\author{
Arınç KAFTAN* \\ Ondokuz Mayıs Üniversitesi, Gıda Mühendisliği Bölümü, Samsun
}

\begin{abstract}
Özet: Evsel ve endüstriyel su kullanımında nüfus artışına bağlı olarak gözlenen artış, atık suların geri kazanımını ve yeniden kullanılmasını gündeme getirmektedir. Sanayideki atık sular, arıtma sonrası, proses suyu ya da soğutma suyu olarak kullanılabilmektedir. Bu kullanım türleri içinde yer alan, soğutma suyu amaçlı kullanım en yaygın olan tür olarak bilinmektedir. Su geri dönüşüm sisteminde, kontaminantları yeteri düzeyde uzaklaştırmak temel amaç olarak benimsenmiştir. Et endüstrisinde ortaya çıkan atık sular, padoklardan, kesimhaneden ve rendering tesislerinden kaynaklanmaktadır. Tavuk mezbahalarında, farklı olarak padoklardan gelen atık sular bulunmamaktadır. Söz konusu atık sular, kan, yağ, etten kaynaklanan protein, yağ ve karbonhidrat içeriği ile BOI ve KOI değerlerinde yükselmeye neden olmaktadır. Et endüstrisi atık su arıtmada flotasyon yöntemi kullanılmaktadır. Flotasyondan sonra damlatmalı filtre ile yapılan arıtma ile BOI değerinde etkin bir düşme sağlanabilmektedir. Kanatlı atık suyunun arıtımı, elekleme, filtrasyon, ozonlama ve klorlama aşamalarını içermektedir. Bu çalışmada entegre et tesislerinde oluşan atık su özellikleri belirtilmiş ve bu tesislerde oluşan atık suyun geri kazanımında kullanılan yöntemler karşılaştırılmıştır.
\end{abstract}

Anahtar kelimeler: Et endüstrisi atık suyu, BOI, KOI, Flotasyon, Filtrasyon.

Abstract: The increasing demand for domestic and industrial water due to growth of population, has raised the need for recycling and reusing of waste water. Industrial waste water could be used either for processing or cooling after its treatment. It has been known that the most common type of use for recycled water is cooling. Removal of contaminants has been considered as the main object in water recycling systems. The effluent from meat industry originates from the stockyards, the slaughterhouse and rendering units. As there is no effluent from stockyards, poultry slaughterhouses differ in the composition of their effluents. The effluent containing blood, fat, and meat protein, fat and carbonhydrate, increase the BOD and COD values of them. The method of flotation has been used for wastewater treatment in meat industry, which can effectively decrease $\mathrm{BOD}$, if it is followed by a trickling filter process. The treatment of poultry wastewater includes screening, filtration, ozonation and chlorination. In this study the characteristics of wastewater of meat processing industry were described, and a comparison between the methods of treatments available for wastewater recycling is carried out.

Key words: Wastewater of meat industry, BOD, COD, Flotation, Filtration.

\section{Giriş}

Sanayi atık suyu, kullanılabilir atık su kaynakları içinde yer almaktadır. Arıtılmış atık sular, sanayide soğutma suyu veya proses suyu olarak yeniden kullanılabilmektedir. Geçen asır sonunda dünya nüfusunun kişi başına y1llık üç yüz elli metreküp olan su gereksinimi içinde, yirmi metreküp'lük kısmını endüstriyel su oluşturmaktaydı (Kavaklı ve Civan, 1997). Suyun en yaygın tekrar kullanım şekli olan soğutma suyu olarak kullanımı ile birlikte çamur oluşumu, korozyon ve köpüklenmenin düşünülmesi gerekmektedir (Hammer and Hammer, 1996). Atık su arıtılmas1 ile ilişkili temel kontaminantlar askıda katı maddeler, biyobozunur maddeler, patojenler, besin maddeleri (azot, fosfor), önemli kirleticiler, zor bozunan organik maddeler, ağır metaller ve çözünmüş inorganik maddeler olarak belirtilmektedir. Atık su için sekonder arıtım, biyobozunur organik maddelerin, süspansiyon halindeki katı maddelerin ve patojenlerin uzaklaştırılmasını içermektedir (Eltem, 2001). Çözünmüş sıvıyı ayırmak amacıyla kullanılan, basınçla geçişme sağlayan membran teknikleri arasında ters ozmoz (1nm'den küçük parçacıklar); nanofiltrasyon (1 ile $5 \mathrm{~nm}$ arasında parçacıklar-şeker); ultrafiltrasyon (5 ile $100 \mathrm{~nm}$ arasında parçacıklar-protein) ve mikrofiltrasyon (100 ile $1000 \mathrm{~nm}$ arasında parçacıklar-bakteri, maya) yer almaktadır. Atık suda temel kirleticiler içinde yer alan protein ve yağın uzaklaştırılmasında ultrafiltrasyon (Avula vd., 2009); askıda katı madde ve yağın birlikte ayrılmasında flotasyon etkili yöntemler olarak bilinmektedir (Öztan, 2003).

\footnotetext{
* İletişim: akaftan@omu.edu.tr
} 


\section{Endüstriyel Atık Su}

Pek çok işletmede, farklı kalitede suya duyulan ihtiyaca göre suyun iki ya da daha çok şekilde kullanımı söz konusudur. Malzeme transferi, seyreltme, çözme, yıkama amacıyla kullanılan ve bazı proseslerde ek arındırmanın da gerekli görüldüğü şehir şebekesinden sağlanan taze su, birinci sınıf su olarak; soğutma ve genel işletme temizliği gibi proses dışı uygulamalar için yeterli düzeyde temiz olduğu düşünülen nehir vb.den sağlanan su da ikinci sınıf su olarak olarak tanımlanmaktadır. Bu iki uygulama arasında yer alan ara kalitede su elde etmek için (örn. kazan besleme suyu) genelde ikinci sinıf suyun ön arıtması gerekmektedir (Bridgwater and Mumford, 1979). Suyun kalitesindeki farklılığa bağlı olarak içme suyu ihtiyacının \%77, geri kazanılan su ihtiyacının \%20 ve ham su ihtiyacının \%3 düzeyinde yer aldığ 1 bildirilmektedir (Matsumura and Mierzwa, 2008). Üretim sırasında oluşan proses atık sularında, çeşitli ham maddeler, ara madde atıkları ve mâmul madde atıkları bulunmaktadır. Proses sularında bulunan organik atıkların bir kısmının oluşumunda gıda endüstrisinin etkili olduğu bilinmektedir. Bu endüstrinin atık suları içinde yer alan karbonhidratlar, atık suyun yüzeysel sulara ulaştığ1 noktalarda mikroorganizma kolonilerinin oluşumu ile çamurların çökmesine/ayrışmasına neden olmaktadırlar (Samsunlu, 1987). Proses suyu, istenmeyen maddeleri uzaklaştırma (örn. sebze işleme) ya da enerji transferini sağlama (örn. soğutma suyu) görevi yapmaktadır. Su geri dönüşüm sisteminin amacı, suyun kalitesini düşüren kontaminantları yeteri düzeyde uzaklaştırmaktır. Endüstriyel suyun geri dönüşüm oranı, gıda sanayinde kaynağına bağlı olarak et için 4, şeker pancarı için $1.5 \mathrm{ve}$ misır/buğday öğütme için 1.2 olarak belirtilmektedir (Bridgwater and Mumford, 1979). Burada geri dönüşüm oran1, belli hacimde geri dönüştürülen suyun ortalama sayısı olarak ifade edilmektedir. Geri dönüşümlü soğutma suyu sistemleri, kullanılan su miktarını düşürmektedir. Farklı soğutma işlemlerinden gelen su, buharlaştırıcı soğutma ünitesine pompalanmakta ve soğutulan su geri dönüştürülmektedir. Soğutma ünitesi, sprey veya soğutma kulesi ile desteklenmiş gölet olabilmektedir (Bridgwater and Mumford, 1979).

\section{DAF (Çözünmüş Hava Flotasyonu)}

Çözünmüş hava ile yüzdürme sistemleri (DAF), flokulasyon ile birlikte kullanıldığında, arıtma tesisi üzerindeki yükün azaltılması, biyolojik arıtma havuzlarındaki Karışık Sıvı Askıda Katı Madde (Mixed Liquor Suspended Solid-MLSS) biyokütle miktarının yüksek tutulması, aktif çamur çöktürme havuzlarındaki yükün azaltılması, ön arıtmanın aktif çamur yoğunlaştırma ile kombine edilmesi gibi üstünlükleri bildirilmektedir (Kluit, 2008). Yüksek katı madde içeren sularda daha büyük yüzey alanına sahip DAF ünitesi; yüksek debide daha düşük katı madde içeren sularda paralel plakalı DAF ünitesi kullanılabilmektedir. Emülsifiye yağ ve gres, çözünmüş proteinler, dispers katı maddeler biyolojik arıtmanın kirlilik yükünü önemli ölçüde arttırmaktadır. Tek başına DAF ile serbest ayrıştırılabilen maddeler dışında yer alan, diğer bileşenleri ayırmak için metal tuzlarıyla, organik koagulantlarla veya asit koagulasyonla ön işlemin ardından polimerlerle flokulasyon yapılabilmektedir. Biyolojik arıtma, çözünmüş organik maddelerin giderimi için iyi bir yöntem olarak bilinmektedir; ancak, askıdaki katı maddelerin, yükü artırdığı eklenmektedir (Kluit, 2008). Atık su içinde yüksek miktarda inorganik katı maddelerin, biyolojik arıtma öncesi, aktif çamur ile giderimi gerekmektedir. DAF ile bu katı maddelerin minimum \%50'si ve ortamdaki yağ ve gresin serbest kısmının biyolojik havuz öncesinde giderimi mümkün olmaktadır. DAF ünitesine flokulator eklenmesi ile mezbaha ve kesimhanelerde \%70-75; tavuk vb. beyaz et kesimhanelerinde \%80-85 KOI giderim verimlerine ulaşıldığı bildirilmektedir (Kluit, 2008). Çöktürme havuzu aşırı yüklendiğinde DAF ünitesi, çöktürme havuzuna paralel kullanılmaktadır. Ayrıca DAF ünitesinden elde edilen \%3-4 KM'de çamurun, konvansiyonel çöktürme havuzlarından çıkan çamura göre 4-6 kat daha konsantre olduğu bildirilmektedir (Kluit, 2008).

\section{Gıda Sanayiinde Su Kalitesi}

Gıdanın bileşiminde bulunan suyun kalitesi, gıdanın kalitesini ve üretim mâliyetini etkilemektedir. Otoklav ve pastörizasyon ünitelerinde kaliteli su kullanılmadığında, ambalaj üzerinde 
kireç lekelerinin oluşumu ile ambalaj görüntüsünün bozulması; kum filtresi kullanan işletmelerde, filtre içinde üreyen mikroorganizmaların klor kullanımında artışa yol açması; kaliteli su ile besleme yapılmayan bir buhar kazanı içinde 1s1 veriminin \%50'lere düşmesi sonucu buhar kullanımının artması, kaliteli su kullanımının önemine ilişkin örnekler olarak sıralanmaktadır (Burkut, 2003).

\section{Et Endüstrisinde Atık Sular}

Su tüketim miktarları, gıda endüstrisinde yer alan sektörlere göre farklılık göstermektedir. Sektörlere bağlı gözlenen bu farkl1lıklar, Çizelge 1'de gösterilmiştir.

Çizelge 1. Endüstri kuruluşlarında su tüketim miktarları (Kavaklı ve Civan, 1997'den adapte)

\begin{tabular}{lcc}
\hline Endüstri & Birim & Su Tüketimi \\
\hline Et kesim & litre/kg & $\mathbf{1 0}$ \\
Tavuk kesim & litre/adet & $\mathbf{3 0}$ \\
Konserve & $\mathrm{m}^{3} /$ ton. ürün & $4-70$ \\
Süt/tereyag & litre/kg & $35-115$ \\
Süt/peynir & litre/kg & $110-195$ \\
Süt/dondurma & litre/kg & $50-100$ \\
\hline
\end{tabular}

Padoklardan çıkan atık su miktarının 20-30 L/m²/gün olduğu ve ortalama $100 \mathrm{mg} / \mathrm{L}$ BOI (Biyokimyasal Oksijen İhtiyacı) içerdiği tahmin edilmektedir (Öztan, 2003). Mezbaha ve entegre et tesislerinde izin verilen kirlilik yükü çıkış değerleri Çizelge 2'de gösterilmiştir.

Çizelge 2. Gıda sanayii (mezbahalar ve entegre et tesisleri) (Anonim, 2004).

\begin{tabular}{lccc}
\hline Parametre & Birim & $\begin{array}{c}\text { Kompozit numune } \\
\text { (2 saatlik) }\end{array}$ & $\begin{array}{c}\text { Kompozit numune } \\
\text { (24 saatlik) }\end{array}$ \\
\hline KOI & $\mathrm{mg} / \mathrm{L}$ & 250 & 160 \\
Yağ ve gres & $\mathrm{mg} / \mathrm{L}$ & 30 & 20 \\
$\mathrm{pH}$ & - & $6-9$ & $6-9$ \\
\hline
\end{tabular}

Kanın yirmi günlük BOI'nın 405000 mg/L, beş günlük BOI'nın 150000-200000 mg/L olduğu belirtilmektedir (Şengül, 1989). Çizelge 3'de görüldüğg̈ gibi mezbaha atık sularının önemli bileşeni olan kanın değerlendirilip değerlendirilmemesi ve ișkembe/bağırsağın atık suya karıșıp karıșmaması, kesimhaneden çıkan atık su miktarını belirlemektedir (Öztan, 2003). Çizelge 4'teki veriler ise atıkların yüksek sıcaklıkta buharla pişirilip, yağdan alındığı, 1slak tip rendering tesislerinde, kuru tipe göre atık su kirliliğinin \%60 daha fazla olduğunu göstermektedir (Öztan, 2003).

Çizelge 3. Et endüstrisinde çıkan atık su kompozisyonu (Öztan, 2003).

\begin{tabular}{|c|c|c|c|c|}
\hline Ünite & $\begin{array}{c}\text { BOI } \\
(\mathrm{mg} / \mathrm{L})\end{array}$ & $\begin{array}{c}\text { Askıda katı miktarı } \\
(\mathrm{mg} / \mathrm{L})\end{array}$ & Organik azot $(\mathrm{mg} / \mathrm{L})$ & $\mathbf{p H}$ \\
\hline Kesimhane & 825 & 220 & 134 & 6.6 \\
\hline Kan toplama tank1 & 3200 & 3690 & 5400 & 9.0 \\
\hline Rendering & 4600 & 8360 & 1290 & 9.0 \\
\hline $\begin{array}{l}\text { İşkembe y1kama } \\
\text { ünitesi }\end{array}$ & 13200 & 15110 & 643 & 6.0 \\
\hline Ürün ünitesi & 800 & 560 & 136 & 7.3 \\
\hline İç yağlar & 180 & 180 & 84 & 7.3 \\
\hline Yan ürün ünitesi & 2200 & 1380 & 186 & 6.7 \\
\hline Toplama atık su & 2240 & 929 & 324 & \\
\hline
\end{tabular}

Çizelge 4. Et Endüstrisinde Birim Üretim Başına Çıkan Atık Su Yükleri* (Öztan, 2003).

\begin{tabular}{lccccc} 
& $\begin{array}{c}\text { Atık su } \\
\left(\mathbf{m}^{\mathbf{3}} \mathbf{t}\right)\end{array}$ & $\begin{array}{c}\text { BOI } \\
(\mathbf{k g} / \mathbf{t})\end{array}$ & $\begin{array}{c}\text { Askıda katı } \\
\text { miktarı (kg/t) }\end{array}$ & $\begin{array}{c}\text { Yă } \\
(\mathbf{k g} / \mathbf{t})\end{array}$ & $\begin{array}{c}\text { Azot } \\
(\mathbf{k g} / \mathbf{t})\end{array}$ \\
\hline Kesimhane & - & 6.4 & 5.2 & 2.8 & 1.58 \\
Kan toplanmıyor & 9.3 & 17.4 & - & - & - \\
Kan toplanıyor & 5.3 & 11.3 & - & - & - \\
İşkembe içeriği var & 14.5 & 11.1 & - & - & - \\
paketleme & 9.3 & 6.3 & 3.0 & - & - \\
Islak rendering & 17.6 & 20.2 & - & - & - \\
Kuru rendering & 10.8 & 14.4 & - & & -59 \\
\hline
\end{tabular}

* canlı ağırlık veya ürün ağırlığı üzerinden 
Şengül (1989) mezbaha atık sularının arıtılmasının ilk aşamasını ızgara ve elekten geçirme ile kıl, et, gübre, yüzen katı maddelerin, askıda katı maddelerin tutulması, yağ tutucular yardımıyla yağ ve gresin atık sudan uzaklaştırılmasını izleyen, daha sonra kullanılacak biyolojik arıtma sisteminin tipine bağlı olarak belirlenen ön çökeltme işlemi uygulaması olarak tanımlamıştır. Damlatmalı filtrasyon ile arıtmada \%81-90; iki kademeli damlatmalı filtrasyon ile \%95 oranında BOI giderme verimi elde edildiğini, biyolojik arıtma amacıyla aktif çamur sistemi (\%90-95 BOI giderimi) veya oksidasyon hendekleri kullanılmakta olduğunu eklemiştir. Bildirildiğine göre et endüstrisi atık suyu arıtmada ise klasik ön çöktürme ve ön arıtma yerine flotasyon kullanılmakta ve bu şekilde yă kapanı olmadan askıda katı partiküller yağ ile birlikte uzaklaştırılmaktadır. Damlatmalı filtrelerde atık sudaki yüksek BOI nedeniyle 5/1 oranında geri besleme yapılmakta ve flotasyondan sonra \%60 BOI arıtımı sağlanmaktadır. Biyolojik arıtma basamağında damlatmalı filtreler, aktif çamur veya anaerobik temas prosesi kullanılmaktadır (Şengül, 1989; Öztan, 2003). Küçük tesislerde anaerobik havuzlarla ön arıtma ile örneğin $22-27^{\circ} \mathrm{C}$ de $200-500 \mathrm{~g} / \mathrm{m}^{3} /$ gün BOI organik yükleme için de $\% 65-80$ arıtma sağlanmaktadır (Öztan, 2003). Mezbaha ve entegre et tesislerinde atık suların arıtılmasında kimyasal arıtmanın yaygın olmadığı ve kimyasal arıtmadan çıkan suyun, sulama suyu olarak kullanılabileceği vurgulanmaktadır (Şengül, 1989). İşletme kolaylığı ve mâliyetinin düşük olması nedeniyle çeşitli endüstri atık sularının arıtımında elektrokoagülasyon yönteminin, entegre et ve et ürünleri endüstrisi atık sularının arıtılmasında alüminyum ve demir elektrotların kullanıldığı, elektrokoagülasyonda en yüksek KOI (Kimyasal Oksijen İhtiyac1) giderim veriminin (\%78.99) aluminyum elektrot ile elde edildiği belirtilmektedir (Özyonar ve Karagözoğlu, 2008). Et endüstrisinde ortaya çıkan atık sular, özellikle padoklardan, kesimhaneden ve rendering tesislerinden ortaya çıkmaktadır. Mezbahalarda büyükbaş ve küçükbaşa ait kirlilik yükleri Çizelge 5'de gösterilmiştir. Tavuk mezbahalarında et endüstrisinden farklı olarak padoklardan gelen atık sular bulunmamaktadır.

Çizelge 5. Mezbahalarda oluşan birim kirlilik yükleri (kg/500 kg canlı ağırlık) (Şengül, 1989).

\begin{tabular}{lcccc}
\hline $\begin{array}{l}\text { Kesilen hayvan } \\
\text { cinsi }\end{array}$ & BOI & Askıda katı madde & Azot & Yağ ve gres \\
\hline Büyükbaş & & & 1 & 0.31 \\
Küçükbaş & 9.40 & 6.70 & 0.49 & 0.25 \\
Ortalama & 4.53 & 5 & 0.75 & 0.28 \\
\hline
\end{tabular}

Kanatlı kesme ve işleme tesislerinde, atık suda, ilk işlem olarak tüy, ayak ve kafanın uzaklaştırılması gerektiği, uygulanan arıtma işlemi ızgaralardan, foseptikten geçirme, lagünlerde biyolojik arıtma olarak sıralanmakta ve bu arıtma aşamalarından çıkışta BOI giderme verimi \%93 olarak bildirilmektedir. (Şengül, 1989). Şekil 1'de görüldüğü gibi kanatlı üretim tesislerinde kanatlı başına 26.5 litre su kullanılmaktadır (Avula vd., 2009). Kanatlı $18 \mathrm{~kg}$ ağırlığa ulaştığında su ihtiyacı 130-150 L/kanatl'yı bulabilmektedir. Kanatlı tesisinde proses suyu; et, kan, deri ve kanatlardan kaynaklanan yağ, protein ve karbonhidrat içermektedir. Bu durum, suda BOI ve KOI değerlerinde yükselmeye neden olmaktadır (Çizelge 6).

Çizelge 6. Tavuk mezbahalarında ortaya çıkan atık su miktarı ve kirlilik yükleri (Anonim, 2008).

\begin{tabular}{lc}
\hline Parametre & Kirlilik yükü \\
\hline Hacim (eski) & $15 \mathrm{~m}^{3} / 1000$ tavuk \\
$\quad$ (yeni) & $27.6 \mathrm{~m}^{3} / 1000$ tavuk \\
Toplam katı madde & $12 \mathrm{~kg} / 1000$ tavuk \\
Askıdaki katı madde & $7 \mathrm{~kg} / 1000$ tavuk \\
Çökebilen katı madde & $4.3 \mathrm{~kg} / 1000$ tavuk \\
yağ & $0.6 \mathrm{~kg} / 1000$ tavuk \\
$\mathrm{BOI}_{5}$ & $13.6 \mathrm{~kg} / 1000$ tavuk \\
\hline
\end{tabular}




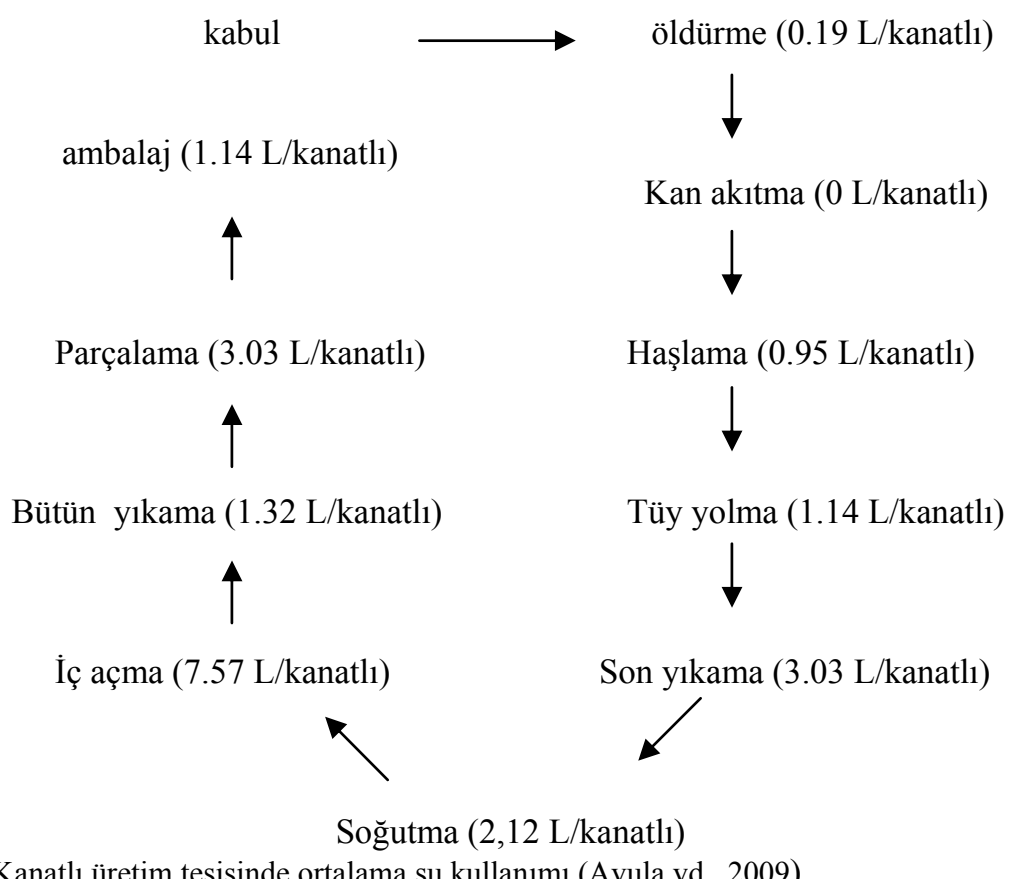

Şekil 1. Kanatlı üretim tesisinde ortalama su kullanımı (Avula vd., 2009).

Aynı kaynakta belirtildiğine göre kanatlı proses suyunun, \%35 protein içerdiği düşünülmekte, atık suyundaki organik materyalin \%80'inin ortalama partikül büyüklüğünün 75-100 mikrometre olduğu bildirilmektedir. Kanatlı atık suyunun arıtımı, elekleme, filtrasyon, ozonlama ve klorlama aşamalarını içermektedir (Çizelge 7).

Çizelge 7. Kanatlı atık suyu arıtımı (Avula vd., 2009).

\begin{tabular}{ll}
\hline Su tipi & Su arıtma yöntemi \\
\hline Karkas yıkama suyu & Elekleme, diatome toprak filtrasyonu, ozonlama, elektriksel \\
& stimulasyon, UV işıllama \\
Ön soğutma, karkas yıkama ve (boyun) soğutma suyu & Flokulasyon ve koagulasyon \\
Haşlama ve soğutma suyu & Elekleme, diatome toprak filtrasyonu, ozonlama \\
Soğutma suyu & Mikrofiltrasyon \\
& a) diatome toprak filtrasyonu, klorlama \\
& b) klorit \\
& c) hidrojenperoksit \\
& d) filtrasyon, ozonlama \\
& e) ozonlama \\
& e) elektroflotasyon \\
\hline
\end{tabular}

Avula vd. (2009) kanatlı atık suyu arıtım işlemlerini yeniden şartlandırma, elektriksel ve optik (elektriksel stimulasyon ve UV ışınlama ile bakteri sayısında azalma); kimyasal ve biyokimyasal (ozonlama ile bakterilerin yok edilmesi, organik maddenin koagulasyon ve flokulasyon ile ayrım, organik maddenin anaerobik filtre veya kesikli reaktör yardımıyla biyolojik parçalanması); fiziksel (DAF, diatome toprak filtrasyonu ve mikrofiltrasyon) olmak üzere üç grup altında değerlendirmektedir. Proses atık suyunda yeniden şartlandırma için mikrobiyal güvenliğin önemli olduğu vurgulamaktadır (Çizelge 8). 
Çizelge 8. Soğutma suyu için tekrar şartlandırma rehberi (Avula vd., 2009).

\begin{tabular}{ccc}
\hline Mikroorganizma azalma \% & Işık geçirgenliği \% & $\begin{array}{c}\text { 1 I taze su için tekrar } \\
\text { şartlandırılan su hacmi \% }\end{array}$ \\
\hline 60 & 60 & 7.75 \\
70 & 70 & 7.50 \\
80 & 80 & 1.35 \\
90 & 80 & 1.25 \\
98 & 80 & 1.10 \\
\hline
\end{tabular}

Et ve kanatlı üretim tesislerinde kullanılan arıtma tesislerindeki su yapılarına göre elde edilen BOI giderim değerleri Çizelge 9'da gösterilmiştir.

Çizelge 9. İşletmelerde kullanılan arıtma tesislerindeki su yapılarına göre BOI giderim değerleri

\begin{tabular}{lccc}
\hline İşletme & Su yapıları & \% BOI giderimi & Kaynak \\
\hline Et & Flotasyon & 60 & (Öztan, 2003) \\
& Anaerobik havuz & $65-80$ & (Öztan, 2003) \\
& Damlatmalı filtre & $81-90$ & (Şengül, 1989) \\
& IŞengül, 1989) \\
\multirow{3}{*}{ Kanatlı } & İki kademeli damlatmalı filtre & 95 & (Şengül, 1989) \\
& Aktif çamur sistemi & $90-95$ & (Avvula vd., 2009) \\
& Ultrafiltrasyon & 97.9 & (Şengül, 1989) \\
\hline
\end{tabular}

\section{Et Endüstrisi Soğutma Suyu ve Kazan Besleme Suyunda Arıtma}

Arıtılmış atık suyun genelde içme suyuna yakın özellikte temiz su olma zorunluluğu, klasik arıtmaya ek olarak ileri arıtma işlemlerinin kullanımını gerektirmektedir. Endüstride suyun geri çevrimi, prosesin bir parçası olarak düşünülmektedir. Büyükkamacı ve Onbaşı (2007) tarafından yapılan çalışmada incelenen et endüstrisi örneğine ait soğutma suyu arıtma tesisi çıkış değerleri Çizelge 10'da; kazan besleme suyu arıtma tesisi çıkış değerleri Çizelge 11'de verilmiştir.

\begin{tabular}{lcc} 
Çizelge 10. Önerilen soğutma suyu özellikleri ve arıtma tesisi çıkış değerleri (Büyükkamacı ve Onbaşı, 2007'den adapte). \\
\hline Parametre (mg/L) & Önerilen limit değer & Arıtma tesisi çıkş̧ı \\
\hline $\mathrm{Cl}^{-1}$ & 500 & 50 \\
Toplam çözünmüş katı madde & 500 & 1068 \\
Sertlik & 650 & 372 \\
Alkalinite (mg/L) & 350 & 330 \\
KOI & 75 & 200 \\
Toplam askıda katı madde & 100 & 16 \\
BOI & 25 & 150 \\
$\mathrm{NH}_{4}^{+}{ }^{-\mathrm{N}}$ & 1.0 & 1.5 \\
$\mathrm{PO}_{4}^{-3}$ & 4 & toplam fosfor=6.49 \\
$\mathrm{SiO}_{2}$ & 50 & 81.5 \\
$\mathrm{Al}^{+3}$ & 0,1 & 0.0075 \\
$\mathrm{Fe}^{-3}$ & 0.5 & 0.5 \\
$\mathrm{Mn}^{+2}$ & 0.5 & 0.15 \\
$\mathrm{Ca}^{+2}$ & 50 & 95 \\
$\mathrm{Mg}^{+2}$ & 0.5 & 300 \\
$\mathrm{SO}_{4}^{-2}$ & 200 & 85 \\
\hline
\end{tabular}

KOI ve BOI değerleri için iki kademeli biyolojik arıtma, diğer parametreler için suda yumuşatma ve filtrasyon önerilmektedir.

Çökelmeye karşı silika, aluminyum ve kalsiyum/magnezyum tuzlarının kontrolu, kazan tipine bağlı filtrasyon, karbon adsorbsiyon ve azot giderimi uygulaması önerilmekte, arıtılmış atık suyun proses suyu olarak kullanılması durumunda içme suyu kalitesinde su elde edilinceye dek arıtma yapılması gerektiği vurgulanmaktadır (Büyükkamacı ve Onbaşı, 2007). 
Çizelge 11. Kazan besleme suyu için önerilen özellikler (Büyükkamacı ve Onbaşı, 2007'den adapte).

\begin{tabular}{|c|c|c|c|c|}
\hline Parametre (mg/L) & $\begin{array}{c}\text { Düşük basınç } \\
\text { (<150 psig) }\end{array}$ & $\begin{array}{c}\text { Orta basınç } \\
(150-700 \text { psig) }\end{array}$ & $\begin{array}{c}\text { Yüksek basınç } \\
\text { (>700 psig) }\end{array}$ & $\begin{array}{c}\text { Atık su arıtma tesisi } \\
\text { çıkışı }\end{array}$ \\
\hline Silika & 30 & 10 & 0.7 & 81.5 \\
\hline Aluminyum & 5 & 0.1 & 0.01 & 0.075 \\
\hline Demir & 1 & 0.3 & 0.05 & 0.5 \\
\hline Mangan & 0.3 & 0.1 & 0.01 & 0.15 \\
\hline Kalsiyum & - & 0.4 & 0.01 & 95 \\
\hline Magnezyum & - & 0.25 & 0.01 & 300 \\
\hline Amonyak & 0.1 & 0.1 & 0.1 & 1.5 \\
\hline Bikarbonat & 170 & 120 & 48 & - \\
\hline Çözünmüş katı madde & 700 & 500 & 200 & 1068 \\
\hline Bakır & 0.5 & 0.05 & 0.05 & $<0.01$ \\
\hline Çinko & - & 0.01 & 0.01 & 0.024 \\
\hline Alkalinite & 350 & 100 & 40 & 330 \\
\hline AKM & 10 & 5 & 0,5 & 16 \\
\hline KOI & 5 & 5 & 1 & 200 \\
\hline
\end{tabular}

\section{Kanatlı Endüstrisi Soğutma Suyunda Arıtma}

Kanatlı endüstrisi soğutma suyu geri kazanımında ozonun kullanılabilirliği ile ilgili Waldroup vd. (1993) tarafından yapılan çalışmada, 580 galonluk dört tankta 7-11.7 ppm düzeyinde ozon otuz dakika süreyle uygulanmış ve toplam aerob, Escherichia coli ve muhtemel koliform düzeyinde \%99'luk düşme yanında 1şık geçirgenliğinin taze suya göre \%88 ile \%99 (540 nm) aralığında olduğu gözlenmiştir. Buna göre geri dönüşüm şartları minimum düzeyde karşılandığında bir galon taze su, 1,75 galon geri dönüşüm suyu yerine kullanılabilmektedir. İdeal koşullarda, soğutma suyunun \%90’ının geri dönüştürülebileceği bildirilmektedir. Ozon tarafından başlatılan oksidasyon, hidroksit oluşumu ve flokulasyon olarak tanımlanan işlem askıda katı maddelerden ve besin maddelerinden oluşan köpük oluşumuna neden olmaktadır. Ozon, doymamış büyük moleküllerle reaksiyona girerek onların daha küçük bileşenlere parçalanması ile arıtılan suyun renginde açılmaya yol açmaktadır. $\mathrm{Bu}$ sistemde artık ozonu uzaklaştırmak için aktif karbon filtrasyon ünitesi de bulunmaktadır. Ozonlama sonrası dört günlük örnekleme boyunca 1şık geçirgenliğinde iyileşme gözlendiği ve aynı süre içinde Escherichia coli ya da toplam koliforma rastlanmadığı bildirilmektedir. Ozonlamadan 1400 saat sonra düşük miktarda aerobik mikroorganizma gözlenmesinin nedeni Waldroup vd. tarafından günün o saatindeki soğutma suyunda mikroorganizma sayısındaki fazlalık yada karkas/su oranındaki değişme olarak açıklanmıştır.

\section{Kanatlı Endüstrisinde Proses Suyunda Arıtma}

Matsumura ve Mierzwa (2008) soğutma suyunda bulunan $600-800 \mathrm{mg} / \mathrm{L}$ düzeyindeki kat1 maddenin \%30-35'ini gres ve yă gibi yüzen maddeler oluşturduğunu belirterek, askıdaki katı maddenin büyük bölümünün opak görünümde olduğu ve emülsiye yağ ile yoğun mikroorganizmadan oluştuğunun, az miktardaki kısmın (\%5-10) $5 \mathrm{~mm}$ partikül büyüklüğünde olup, emülsiye globule bağlı olduğunun düşünüldüğünü eklemektedirler. Söz konusu araştırmada ultrafiltrasyon ile arıtma sonucu, proses suyundaki KOI değerinin \%59 oranında azaltılabildiği, soğutma suyu ve ön yıkama suyunun ultrafiltrasyon ve iç açma suyu kaba filtrasyonu ile toplam bakteri sayımında (\%98.4), koliform (\%86.6), BOI (\%97.9), KOI (\%96.6), yağ ve gres (\%79.8), partikül büyüklüğü dağılımı (\%70.2) ve su kullanımında $17 \mathrm{~L} /$ kanatlı düşme gözlenmiştir. Mikrobiyal alıkonma için ultrafiltrasyon ideal membran gözenek büyüklüğü, 0,05 mikrometre olarak verilmektedir (Avula vd., 2009). Gıdayla temas eden suyun içme suyu kalitesinde olması gerekliliği, biyolojik kontaminasyonun önemini arttırmaktadır. Kan, emülsiye yağ ve dışkının (Salmonella spp., Camphylobacter jejuni) yüksek BOI değeri ile ilişkili olduğu bilinmektedir (Matsumura ve Mierzwa, 2008). 


\section{Sonuç}

Tüketicilerden gelen talebe bağlı olarak üretim miktarındaki artış daha fazla su kullanımına yol açmaktadır. Suyun geri kazanımında amaç, toplam su kullanımında azalmaya yol açarak üreticiye ekonomik yönde katkıda bulunmaktır. Kirlilik yüklerinin yüksek olduğu bilinen entegre et ve kanatlı üretim tesislerinde kullanılan damlatmalı filtrasyon, aktif çamur sistemi, ultrafiltrasyon gibi arıtma yöntemleri ile BOI değerinde etkili arıtma verimi elde edilmektedir. Kullanılan farklı yöntemler içinde ultrafiltrasyon yöntemi ile proses suyundaki KOI değerinde azalması ile birlikte, ham protein gibi katma değer yaratan ürünlerin ayırımı sağlanabilmektedir. Suyun geri kazanımı ile ilgili yapılacak çalışmaların, özellikle çok su kullanan ve çok atık su oluşumuna yol açan sektörler için büyük önem taşıdığı düşünülmektedir.

\section{Kaynaklar}

Anonim, 2004. Su Kirliliği Kontrolü Yönetmeliği, Resmi Gazete, Sayı 25687.

Anonim, 2008. http://www.eng.ege.edu.tr/otles/foodwaste-meat.tripod.com

Avula R.Y. Nelson H.M. ve Singh R.K. 2009. Recycling of Poultry Process Wastewater by Ultrafiltration, Innovative Food Science and Emerging Technologies, 10: 1-8.

Burkut E. 2003. Gıda Sanayinde Proses Suyu Kalitesinin ve Su Hazırlamanın Ürün Maliyetine Etkisi, GIDA-Şubat, s.45-46.

Bridgwater A.V and Mumford C.J. 1979. Materials Recovery from Liquid Waste, Waste Recycling and Pollution Control Handbook, George Godwin Ltd., Great Britain, p.252-259.

Büyükkamacı N. ve Onbaşı A.N. 2007. Endüstriyel Atık Suların Yeniden Kullanımının Değerlendirilmesi: Entegre Et Tesisi Atık suları, 7. Ulusal Çevre Mühendisliği Kongresi Bildiri Kitab1, İzmir, s.502-510.

Eltem R. 2001. Atık Sular ve Arıtım, Ege Üniversitesi Fen Fakültesi Yayınları No:172, 188s.

Hammer M.J ve Hammer M.J.J. 1996. Water Reuse, Water and Wastewater Technology, 3 'th edition, Prentice-Hall Inc., 519p.

Kavakl1 M. ve Civan Z. 1997. Türkiye'de Su Kullanımı, Atık suları Geri Kazanma ve Yeniden Kullanma Uygulamaları, Su ve Çevre Sempozyumu Bildiri Kitabı, İstanbul.

Kluit A. 2008. Biyolojik Arıtmanıza İkinci Bir Şans Verin, Çulha E., (çev.) Su ve Çevre, Sayı: 20.

Matsumura E.M ve Mierzwa J.C. 2008. Water Conservation and Reuse in Poultry Processing Plant-a Case Study. Resources, Conservation and Recycling, 52: 835-842.

Öztan A. 2003. Et Bilimi ve Teknolojisi, TMMOB Gıda Mühendisleri Odası, yayın no:1, 4.bask1, $495 \mathrm{~s}$, Ankara.

Özyonar F ve Karagözoğlu B., 2008, Entegre Et ve Et Ürünleri Endüstrisi Atık Sularının Elektrokoagülasyon Yöntemiyle Arttılabilirliğinin Araştırılması, 11.Endüstriyel Kirlenme Kontrolü Sempozyumu Bildiri Kitabı, İstanbul, s.125-132.

Samsunlu A. 1987. Kullanılmış Suların Arıtılması, Dokuz Eylül Üniversitesi Müh-Mim.Fakültesi MM/ÇEV-87 EY 106, 301s.

Şengül F.1989, Endüstriyel Atık suların Özellikleri ve Arıtılmas1, Dokuz Eylül Üniversitesi MühMim.Fakültesi MMF/ÇEV-89 EY 172, 476s.

Waldroup A.L., Hierholzer R.E., ve Forsythe R.H. 1993. Recycling of Poultry Chill Water Using Ozone, Journal of Appl. Poultry Res., 2: 330-336. 